\title{
MENGUNGKAP TINGGINYA TURNOVER INTENTION \\ PT. WBS SEMARANG
}

\author{
Delita Sari \\ Susanto \\ Fakultas Ekonomi Universitas Semarang \\ Diterima: Februari 2019, Disetujui: Maret 2019. Dipublikasikan: April 2019
}

\begin{abstract}
ABSTRAC
This research aimed at obtaining information profoundly concerning the factors of the work movement desire (intention turnover) of the employees in PT. WBS Semarang.

This was a qualitative research. Data qualitative collection was condukted through an observation, a profound intervew and a documentary study. The informants in the reserarch were seven employees consisting of three ex-employees, three employees who still working and one employee from HRD departement in PT.WBS Data analysis used triangulation method.

The results showed that the employees intention turnover caused by the compensation does not match with the expectations of employees and internal motivation to look for another experience with a better offer.

Keywords: compensation, internal motivation, and turnover intention
\end{abstract}

\begin{abstract}
ABSTRAK
Penelitian ini bertujuan memperoleh informasi secara mendalam tentang faktor keinginan pindah karyawan di PT. WBS Semarang.

Penelitian ini adalah penelitian kualitatif. Pengumpulan data kualitatif dilakukan melalui observasi, wawancara mendalam dan telaah dokumen. Informan dalam penelitian berjumlah 7 orang yang terdiri atas 3 mantan karyawan , 3 karyawan yang masih aktif bekerja dan 1 orang bagian personalia di PT. WBS Semarang. Teknik analisis data menggunakan analisis trianggulasi.

Hasil penelitian menunjukan bahwa karyawan berkeinginan keluar karena dilatarbelakangi adanya kompensasi yang tidak sesuai dengan harapan karyawan maupun motivasi dari diri sendiri untuk mencari pengalaman lain dengan penawaran yang lebih baik.

Kata kunci : kompensai, motivasi internal dan turnover intention.
\end{abstract}

\section{PENDAHULUAN}

Sumber daya manusia merupakan subyek utama yang berperan dalam perusahaan untuk mencapai keberhasilannya. Sumber daya manusia merupakan satu - satunya sumber daya yang memiliki akal perasaan, keinginan, ketrampilan, pengetahuan, dorongan daya dan karsa. Semua potensi sumber daya manusia tersebut berpengaruh terhadap upaya organisasi dalam mencapai tujuan. Betapapun majunya teknologi, perkembangan informasi, tersedianya modal dan memadainya bahan, jika tanpa sumber daya manusia sulit bagi organisasi untuk mencapai tujuannya (Edy Sutrisno, 2009)

Karyawan sebagai sumber daya manusia yang dimiliki oleh restoran menempati posisi strategis dalam sebuah perusahaan diantara sumber daya lainnya, sehingga untuk 
dapat menghasilkan output yang sesuai dengan harapan perusahaan, sudah seharusnya sumber daya manusia dikelola dan dimanfaatkan dengan sebaik - baiknya .

Restoran adalah suatu bidang usaha selain menjual produk makanan juga menjual jasa. Hal ini peran karyawan terutama yang berkaitan langsung dengan pelayanan sangat penting agar dapat menghasilkan atau memberikan pelayanan yang baik (service excellence) dengan harapan tidak akan terjadi komplain atau keluhan dari para pelanggan karena pelayanan yang diberikan sangat memuaskan. Ketika pelanggan merasa puas karena pelayanan yang diberikan oleh karyawan adalah sangat baik, hal ini membuktikan bahwa perusahaan mampu memimpin karyawan tersebut untuk dapat bekerja sesuai standar yang ditentukan perusahaan.

Fenomena yang sering terjadi adalah kinerja suatu perusahaan yang telah demikian bagus dapat dirusak, baik secara langsung maupun tidak oleh berbagai perilaku karyawan yang sulit dicegah terjadinya. Salah satu bentuk perilaku karyawan yang menentukan kinerja suatu perusahaan adalah keinginan untuk keluar.

Saat ini tingginya tingkat intensi turnover telah menjadi masalah serius bagi banyak perusahaan. Bahkan beberapa perusahaan mengalami frustasi ketika mengetahui proses rekrutmen yang telah berhasil menjaring staf yang berkualitas pada akhirnya ternyata menjadi sia-sia karena staf yang direkrut tersebut telah memilih pekerjaan diperusahaan lain (Handaru dan Muna, 2012). Dampak negatif yang dirasakan akibat terjadinya turnover pada perusahaan yaitu pada kualitas dan kemampuan untuk menggantikan karyawan yang keluar dari perusahaan, sehingga butuh waktu serta biaya baru dalam merekrut karyawan baru.

Dengan tingginya tingkat turnover pada perusahaan akan semakin banyak menimbulkan berbagai potensi biaya baik itu pelatihan yang sudah diinvestasikan pada karyawan, tingkat kinerja yang selalu dikorbankan, maupun biaya rekrutmen dan pelatihan kembali (Suwandi dan indriantoro, 1999)

Peneliti ini mengambil objek pada PT. WBS sebuah perusahaan yang bergerak dibidang restoran dengan sajian chinnese food atau masakan cina buka setiap hari untuk makan siang 11.30 WIB - 14.30 WIB dan makan malam 17.30 WIB - 22.00 WIB. Hari minggu dan hari libur tetap buka dari jam 08.00 WIB - 14.30 WIB dan 17.30 WIB 22.00 WIB. Perusahaan ini mengalami turnover yang tinggi. Hal ini dapat dilihat berdasarkan data keluar masuk karyawan tahun 2015 
Presentase keluar masuknya karyawan

PT. WBS Semarang

Tahun 2015

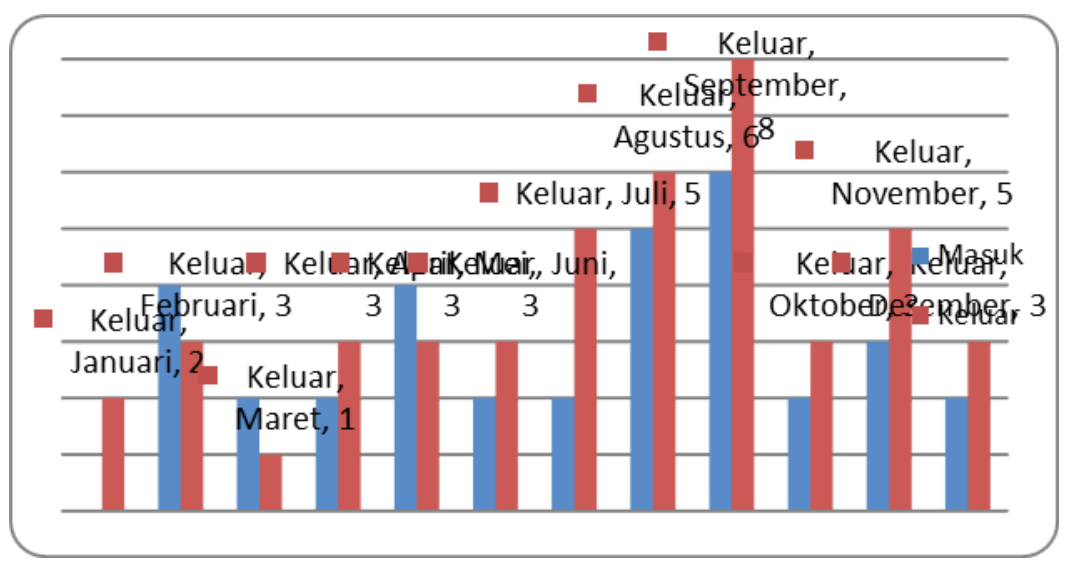

Sumber data : HRD PT. WBS

Dari tabel diatas terlihat bahwa turnover semakin meningkat tahun 2015. Hampir setiap bulan selalu ada karyawan yang keluar dan masuk, namun presentase karyawan masuk lebih sedikit daripada presentase karyawan yang keluar. Sehingga bisa dilihat dari data diatas jika ada masalah di perusahaan tersebut. Dilihat dari bulan juli hingga september selalu mengalami peningkatan jumlah karyawan yang keluar dan jika ditotal sudah ada 45 karyawan yang keluar dan sudah pasti ini berdampak negatif untuk PT. WBS itu sendiri.

Masalah Turnover juga mengakibatkan perusahaan tidak efektif karena kehilangan karyawan yang berpengalaman dan ini berarti PT. WBS perlu melatih kembali karyawan baru (Woods dan Macaulay, 1989). Hal ini berdampak pada terganggunya operasi PT. WBS, sehingga menimbulkan kerugian dari sisi moral maupun financial.

Jika dilihat dari latar belakang yang sudah diuraikan diatas, perlu untuk dilakukan penelitian lebih lanjut secara langsung guna membahas masalah tersebut dengan judul "Mengungkap Tingginya Turnover Intention PT. WBS Semarang". 


\section{TINJAUAN PUSTAKA}

\section{Turnover Intention}

Turnover Intention (keinginan berpindah) mencerminkan keinginan individu untuk meninggalkan organisasi dan mencari alternatif pekerjaan (Suwandi dan Indriantoro, 1999). (Abelson, 1987) menggambarkan hal tersebut sebagai pikiran untuk keluar, mencari pekerjaan ditempat lain, serta keinginan meninggalkan organisasi.

Turnover Intention (Intensi keluar) adalah kecenderungan atau niat karyawan untuk berhenti bekerja dari pekerjaannya (Zeffane, 1994). Menurut bluedom dalam Grant et al, (2001) Turnover Intention adalah kecenderungan sikap atau tingkat dimana seorang karyawan memiliki kemungkinan untuk meinggalkan organsasi atau mengundurkan diri secara sukarela dari pekerjaanya. Lebih lanjut dijelskan Mobley, horner dan holling sworth, 1978 dalam Grant et al, (2001) keinginan untuk pindah dapat dijadikan gejala awal terjadinya Turnover dalam sebuah perusahaan. Intensi keluar (Turnover Intention) juga dapat diartikan sebagai pergerakan tenaga kerja keluar dari organisasi. Turnover dapat berupa pengunduran diri, perpindahan keluar unit organisasi, pemberhentian atau kematian anggota organisasi.

Robbins (1996), menjelaskan bahwa Turnover dapat terjadi secara sukarela (Voluntary trunover) maupun secara tidak sukarela (involuntary turnover). Voluntary turnover atau quit merupakan keputusan karyawan untuk meninggalkan organisasi secara sukarela yang disebabkan oleh faktor seberapa menarik pekerjaan lain. Sebaliknya, involuntary turnover atau pemecatan menggambarkan keputusan pemberian kerja (employer) untuk menghentikan hubungan kerja dan bersifat uncontrollable bagi karyawan yang mengalaminya.

\section{Faktor - Faktor Turnover Intention}

Menurut Mobley et al (1978) menyebutkan beberapa faktor yang menjadi penyebab keinginan pindah kerja (turnover intention) adalah sebagai berikut :

1) Karakteristik Individu

Organisasi adalah wadah yang memiliki tujuan yang ditentukan secara bersama oleh orang - orang yang terlibat didalamnya. Untuk mencapai tujuan tersebut, maka diperlukan adanya interaksi yang berkesinambungan dari unsur - unsur organisasi. 
Karakter individu yang mempengaruhi keinginan pindah kerja antara lain seperti umur, pendidikan, status perkawinan.

2) Lingkungan Kerja

Lingkungan kerja dapat meliputi lingkungan fisik maupun sosial. Lingkungan fisik meliputi keadaan suhu, cuaca, kontruksi, bangunan dan lokasi pekerjaan. Sedangkan lingkungan sosial meliputi sosial budaya di lingkungan kerjanya dan kualitas kehidupan kerjanya.

3) Kepuasan Kerja

Pada tingkat individual, kepuasan merupakan varial psikologi yang paling sering diteliti dalam suatu model intention to leave. Aspek kepuasan yang ditemukan berhubungan dengan keinginan individu untuk meninggalkan organisasi meliputi kepuasan akan gaji dan promosi, kepuasaan atas supervisor yang diterima, kepuasan dengan rekan kerja dan kepuasan akan pekerjaan dan isi kerja.

4) Komitmen Organisasi

Perkembangan selanjutnya dalam studi intention to leave memasukan konstruksi komitmen organisasional sebagai konsep yang turut menjelaskan proses tersebut sebagai bentuk perilaku, komitmen mengacu pada respon emosional (affective) individu kepada keseluruhan organisasi, sedangkan keputusan mengarah pada respon emosional atas aspek khusus dari pekerjaan.

\section{Dampak Turnover Intention}

Menurut Mobley et al (1978) tinggi rendahnya turnover intention akan membawa beberapa dampak pada karyawan maupun perusahaan, antara lain :

1) Beban kerja, jika turnover intention karyawan tinggi, beban kerja untuk karyawan bertambah karena jumlah karyawan berkurang. Semakin tinggi keinginan karyawan untuk meninggalkan perusahaan, maka semakin tinggi pula beban kerja karyawan selama itu.

2) Biaya penarikan karyawan. Menyangkut waktu dan fasilitas untuk wawancara dalam proses seleksi karyawan, penarikan dan mempelajari penggantian karyawan yang mengundurkan diri.

3) Biaya latihan. Menyangkut waktu pengawas, departemen personaliadan karyawan yang dilatih. Pelatihan ini diberikan untuk karyawan baru. Jika turnover 
intention tinggi dan banyak karyawan yang keluar dari perusahaan, maka akan mengakibatkan peningkatan pada biaya pelatihan karyawan.

4) Adanya produksi yang hilang selama masa pergantian karyawan. Dalam hal ini, berkurangnya jumlah karyawan akan mengurangi jumlah produksi atau pencapaian target penjualan. Ini akibat dari tingginya turnover intention. Terlebih bila karyawan yang keluar adalah karyawan yang memiliki tingkat produktivitas yang tinggi.

5) Banyak pemborosan karena adanya karyawan baru. Imbas dari tingginya turnover karyawan membuat perusahaan mengeluarkan biaya - biaya yang sebenarnya bisa dihindari jika dapat mengelola SDM dengan baik agar karyawan dapat bertahan lama diperusahaan.

6) Memicu stres karyawan. Stres karyawan dapat terjadi karena karyawan lama harus beradaptasi dengan karyawan baru. Dampak yang paling buruk dari stres ini adalah memicu karyawan yang tinggal untuk berkeinginan keluar dari perusahaan.

\section{METODOLOGI PENELITIAN}

Penelitian ini adalah sebuah penelitian kualitatif yang didasarkan pada fenomena, gejala, fakta atau informasi sosial. Menurut Bogdan dan Taylor yaitu prosedur penelitian yang menghasilkan data deskriptif berupa kata-kata tertulis atau lisan dari orang - orang atau perilaku yang dapat diamati. Pendekatan ini diarahkan pada latar dan individu tersebut secara utuh (holistic), tidak mengisolasi individu ke dalam variabel, tetapi perlu memandangnya sebagai bagian dari suatu keutuhan (Lexy J. Moleong, 2005)

Penelitian ini menggunakan metode deskriptif kualitatif yang bertujuan untuk memahami femomena sosial dari sudut pandang atau perseptif partisipan. Partisipan adalah orang yang diajak berwawancara, diobservasi, dimintai data, pendapat, pemikiran, dan persepsinya. Penelitian deskriptif merupakan penelitian yag berusaha mendeskripsikan dan menginterprestasikan sesuatu, misalnya kondisi atau hubungan yang ada, pendapat yang berkembang, proses yang sedang berlangsung, akibat atau efek yang terjadi, atau tentang kecenderungan yang tengah berlangsung. Furchan menjelaskan bahwa penelitian deskriptif adalah penelitian yang dirancang untuk memperoleh informasi tentang suatu gejala saat penelitian dilakukan (A.Furchan, 2004). 


\section{Setting Penelitian}

Subyek dalam penelitian ini adalah 3 mantan karyawan dan 3 karyawan aktif PT. WBS. Alasan memilih subyek penelitian tersebut adalah dikarenakan peneliti memiliki anggapan bahwa perlu untuk mengetahui penyebab tingginya turnover di PT. WBS.

\section{Pemilihan Informan}

Informan atau narasumber adalah orang yang memberikan informasi utama dan penting yang dibutuhkan peneliti dalam sebuah penelitian. Informan dijadikan sebagai subjek utama dalam sebuah penelitian.

Menurut Moleong (2004) mendefinisikan informan sebagai orang yang memberikan informasi tentang situasi dan kondisi latar penelitian. Orang yang dijadikan informan haruslah mereka yang jujur, taat pada janji, patuh pada peraturan, suka berbicara, tidak termasuk anggota salah satu kelompok yang bertentangan dengan latar penelitian, dan mempunyai pandangan tertentu tentang sesuatu hal atau tentang peristiwa yang terjadi. Bogdan dan biklen yang dikutip Moleong (2004) menyatakan bahwa pemanfaatan informan bagi peneliti ialah agar dalam waktu yang relatif singkat banyak informasi yang terjangkau.

\section{Metode Pengumpulan Data}

\section{Wawancara Mendalam ( in depth interview)}

Wawancara yang dilakukan dalam penelitian ini adalah wawancara mendalam (in depth interview) melalui wawancara tak berstuktur. Dengan wawancara tak berstruktur, perumusan dan urutan pertanyaan dapat lebih bebas sehingga akan lebih dapat mengikuti alur pembicaraan responden. Sulistyo - basuki menyebutkan bahwa wawancara mendalam ialah mengumpilkan informasi yang kompleks, sebagian besar berisi pendapat, sikap dan pengalaman pribadi. Sasaran wawaancara mendalam ialah menyelenggarakan wawancara yang memungkinkan para responden membahas secara mendalam sebuah subjek (Sulistyo-Basuki, 2006)

Pernyataan dari peneliti sangatlah penting untuk menangkap persepsi, pikiran, pendapat, perasaan orang tentang suatu gejala, peristiwa, fakta dan realita. Dalam melakukan wawancara peneliti akan merekam setiap pertanyaan yang diajukan dan jawaban yang diberikan oleh informan. Sebelum melakukan wawancara yang dilakukan akan meminta izin kepada informan bahwa wawancara yang dilakukan akan direkam 
dan memberikan jaminan kepada informan bahwa hasil rekaman akan digunakan untuk kepentingan penelitian dan digunakan untuk peneliti saja. Wawancara yang direkam akan memberi nilai tambah, yakni dengan rekaman peneliti akan mendapatkan bukti asli suara dari informan dan akan menjadi bukti otentik apabila nantinya terdapat kesalah penafsiran. Data yang telah direkam kemudian di tulis kembali dan diringkas. Setelah diringkas maka akan dianalisis dan dicari tema serta polanya.

\section{Observasi}

Observasi adalah pengamatan dan pencatatan yang sistematis terhadap gejala-gejala yang diteliti (Usman, 2008). Dalam hal ini, peneliti dengan berpedoman kepada desain penelitiannya telah melakukan observasi ke lokasi penelitan untuk mengamati langsung berbagai hal atau kondisi yang ada dilapangan.

Dalam pelaksanaan observasi dilakukan dengan cara observasi partisipan. Observasi partisipan adalah observasi yang dilakukan oleh peneliti yang berperan sebagai anggota yang berperan serta dalam kehidupan masyarakat ( Emzir, 2012) topik dalam penelitian ini untuk memperoleh gambaran secara jelas mengenai aktivitas, perilaku dan peristiwa yang terjadi di PT. WBS.

\section{Triangulation}

Untuk menguji keabsahan data dalam penelitian kualitatif, sehingga data yang ada valid dan dapat dipertanggungjawabkan, peneliti akan melakukan Triangulasi (Check dan Recheck). Metode triangulasi yaitu teknik pemeriksaan keabsahan data yang memanfaatkan sesuatu yang lain diluar data itu untuk keperluan pengecekan atau sebagai pembanding terhadap data itu.

Dalam penelitian ini, triangulasi yang dianggap relevan untuk menguji keabsahan data adalah dengan melakukan triangulasi sumber dan teknik. Triangulasi teknik, berarti untuk menguji kredibilitas data dilakukan dengan cara mengecek data pada sumber yang sama dengan teknik yang berbeda, misalnya data diperoleh melalui wawancara, lalu dicek dengan observasi, dan dokumentasi. Pada triangulasi teknik, menurut Patton terdapat dua strategi yaitu (Moleong, 2005)

1. Pengecekan derajat kepercayaan penemuan hasil penelitian beberapa teknik pengumpulan data 
2. Mengecekan derajat kepercayaan beberapa sumber data dengan metode yang sama

Triangulasi sumber berarti untuk menguji kredibilitas data dilakukan dengan cara mengecek data yang telah diperoleh ke beberapa sumber (Sugiyono, 2005)

\section{HASIL DAN PEMBAHASAN}

Penelitian telah melakukan observasi untuk menentukan informan yang sesuai dengan kriteria yang telah ditentukan sebelumnya. Informan yang telah diambil berjumlah 7 orang yang diambil dari masing - masing divisi di PT. WBS.

Berdasarkan hasil penelitian yang diperoleh dari wawancara dengan informan peneliti memperoleh 2 variabel yaitu :

\section{Kompensasi}

Salah satu faktor yang mempengaruhi kepuasan kerja adalah kompensasi. Kompensasi adalah semua pendapata yang berbentuk uang barang langsung atau tidak langsung yang diterima karyawan sebagai imbalan atas jasa yang diberikan kepada perusahaan (Hasibuan, 2008).

Berdasarkan temuan peneliti yang diperoleh dari hasil wawancara dengan informan, terungkap bahwa rata - rata standar gaji karyawan di PT. WBS tersebut belum mampu menyesuaikan dengan UMR Semarang. Artinya rata-rata karyawan yang bekerja diperusahaan tersebut belum mampu mencukupi kebutuhan sosialnya sesuai dengan standar minimal kehidupan yang layak dikota semarang.

Kompensasi lain yang diberikan perusahaan kepada karyawan adalah tunjangan prestasi. Prestasi karyawan dinilai oleh pihak manajemen, tolak ukur yang menentukan penilaian kinerja seorang karyawan adalah dilihat dari beberapa hal yaitu absensi, kejujuran, dan kedisiplinan. Besarnya tunjangan prestasi yang diterima karyawan berbeda satu dengan yang lainnya tergantung dari penilaian pihak manajemen terhadap kinerja karyawan. Sedangkan penilaian dari pihak manajemen seringkali kurang obyektif, hal ini membuat karyawan merasa menerima ketidakadilan dan ketidakpuasan dari pihak perusahaan. Selain itu, kompensasi lain yang di terima karyawan adalah jaminan kesehatan BPJS. Jaminan kesehatan BPJS diberikan kepada karyawan dengan masa kerja minimal dua tahun. 


\section{Motivasi}

Motivasi Internal adalah motivasi yang timbul dari diri sendiri. Motivasi internal adalah motivasi paling kuat karena tidak dapat dipengaruhi oleh motivasi eksternal atau lingkungan. Motivasi internal juga tidak dapat di pengaruhi oleh motivasi eksternal ataupun sebaliknya motivasi eksternal tidak dapat dipengaruhi oleh motivasi internal.

Timbulnya motivasi internal disebabkan karena adanya kebuttuhan dan keinginan yang ada di dalam diri seseorang. Kekekuatan ini akan mempengaruhi pikirannya, yang selanjutnya akan mengarahkan perilaku orang tersebut. Sebagai contoh, seorang karyawan yang ingin mendapatkan nilai yang memuaskan dalam menilaian kinerja akan mementukan perilaku karyawan dalam memenuhi syarat penilaian tersebut. Setelah memikirkan dalam-dalam, perilakunya mungkin akan menjadi karyawan yang rajin dalam bekerja, tidak datang terlambat, tidak pernah absen dan mematuhi peraturan, tetapi dalam kenyataan tidak semua karyawan mempunyai keinginan yang kuat untuk mencapai nilai yang memuaskan.

Usia rata-rata informan dalam penelitian ini berkisar antara 20 sampai dengan 26 tahun dengan latar belakang pendidikan menengah keatas (SMA / SMK) dan lama kerja yang bervariasi. Hal ini membuat seorang karyawan memiliki kesempatan yang jauh lebih banyak dalam mengembangkan karir di dalam perusahaan dibandingkan dengan karyawan lain yang usianya jauh lebih diatas mereka. Karena usia mereka termasuk dalam kategori usia produktif. Dimana dalam masa usia produktif, seseorang memiliki semangat di dalam dirinya untuk mengejar atau meraih sesuatu dengan tujuan peningkatan karir dan peningkatan salary.

Dengan usia produktif dan masa kerja yang relatif belum terlalu lama, seorang karyawan yang merasa bahwa perusahaan tempatnya bekerja belum mampu memberikan timbal balik yang sesuai dengan output yang diberikan karyawan terhadap perusahaan, membuat karyawan akan mencari kesempatan di luar. Tidak hanya dari segi salary, namun mereka juga dapat mengembangkan diri dari segi pengalaman. Alasan seorang karyawan mengundurkan diri salah satunya adalah karena adanya tawaran yang lebih menguntungkan dari perusahaan tempatnya bekerja, seperti gaji dan tunjangan yang lebih besar. Maka dari itu saat mereka tiba tiba memperoleh tawaran pekerjaan di prusahaan lain dengan gaji yang lebih baik, bisa jadi mereka kemudian akan memutuskan untuk mengundurkan diri. Apalagi jika para karyawan ternyata tidak 
pernah mendapat penawaran yang bagus dari perusahaan selama mereka bekerja. Hal ini akan semakin membuat karyawan dengan yakin untuk mengundurkan diri ketika mendapat tawaran yang lebih baik dari perusahaan yang lain.

\section{PENUTUP}

\section{Kesimpulan}

Tingginya tingkat turnover intention di PT. WBS di latarbelakangi adanya kompensasi yang tidak sesuai dengan harapan karyawan. Karyawan merasa kurang menerima ketidakseimbangan antara output yang diberikan karyawan kepada perusahaan dan input yang diberikan perusahaan kepada karyawannya. Karyawan menilai bahwa output yang telah diberikan kepada perusahaan tidak setimpal dengan kompensasi yang mereka terima dari perusahaan. Hal ini menyebabkan seorang karyawan memilih untuk mengundurrkan diri dari perusahaan. Banyaknya penawaran yang lebih baik dari perusahaan lain, usia produktif dan masa kerja yang relatif belum terlalu lama membuat tingkat turnover di perusahaan semakin meningkat. Setiap perusahaan memiliki standar tertentu dalam memberikan kompensasi kepada karyawannya. Dasar yang digunakan perusahaan untuk memberikan kompensasi kepada karyawannya di ambil dari jumlah omset atau pendapatan yang dihasilkan perusahaan. Perlu adanya pemahaman yang sama antara karyawan dan perusahaan mengenai adil tidaknya atau seimbang tidaknya dalam pemberian kompensasi sehingga seorang karyawan akan berpikir ulang untuk berpindah kerja dan tetap survive dalam perusahaan hanya karena alasan kompensasi maupun motivasi dari diri sendiri untuk mencari pengalaman lain dengan penawaran yang lebih baik.

\section{Saran}

Mengingat keterbatasan penulis, terdapat beberapa hal yang tidak dapat dilakukan dalam penelitian ini. Oleh karena itu, saran-saran yang diberikan untuk penelitian selanjutnya guna tercapainya penelitian yang lebih baik adalah :

1. Penelitian berikutnya disarankan untuk memperbanyak informan, sehingga hasil yang diperoleh lebih mendekati kondisi yang sesungguhnya.

2. Penelitian berikutnya disarankan untuk melakukan survey pendahuluan untuk menentukan variabel-variabel yang lebih spesifik bagi turn over pekerja. 
Dengan variabel yang lebih spesifik maka diharapkan akan mengurangi variabel yang tereduksi pada proses analisis. Penelitian dilakukan lebih spesifik dan lebih detail mengenai jenis perusahaan sehingga dapat diketahui faktor-faktor yang mempengaruhi turnover.

3. Hasil dari penelitian faktor-faktor yang mempengaruhi turn over pekerja hendaknya dikaitkan dengan kinerja perusahaan sehingga dapat memberikan manfaat yang lebih aplikatif terhadap perusahaan

4. Secara manajemen SDM turn over pekerja merupakan hal yang tidak dapat dihindari. Dengan semakin banyaknya penelitian mengenai turn over pekerja hendaknya pihak yang terkait dengan manajemen SDM memberikan perhatian yang lebih banyak untuk menyikapi masalah turn over sehingga tidak banyak mengganggu kinerja perusahaan.

5. Lebih banyak dilakukan penelitian jenis kualitatif karena penelitian jenis ini masih sangat jarang.

\section{DAFTAR PUSTAKA}

Ahmad Tohardi, (2002), Pemahaman Praktis Manajemen Sumber Daya Manusia, Universitas Tanjung Pura, Mandar Maju, Bandung

Anwar Prabu Mangkunegara. (2009). Evaluasi Kinerja SDM, Jakarta: Eresco.Bluedom A. 1982. Investment in human capital : A Theoretical analysis J Political Econom 70 (5) 9-49

A. Furchan, Pengantar Penelitian dalam Pendidikan. (Yogyakarta: Pustaka Pelajar. ,2004 ), hal. 447

Emzir 2012. Metodologi Penelitian Kualitatif. Jakarta : Rajawali Press

Handaru, A, W \& Muna, N (2012) Pengaruh kepuasan gaji dan komitmen organisasi terhadap intensi turnover pada devisi PT. Jamsostek. Jurnal riset manajemen sains Indonesia, 3, 1-9

Harnoto (2002) manajemen sumber daya manusia, Jakarta : Prehallindo 
Hasibuan, Malayu S. P. (2008). Manajemen Sumber Daya Manusia, Jakarta : Bumi Aksara.

Lexy J. Moleong, Metodologi Penelitian Kualitatif. (Bandung: Remaja Rosdakarya.2005), hal. 3

Mahmudi, (2005). Manajemen Kinerja Sektor Publik. Yogyakarta : UPP AMP YKPN.

Rachmat Kriyantono. Teknik praktis riset komunikasi: Disertai contoh praktis riset media, public relations, advertising, komunikasi organisasi, komunikasi pemasaran. Jakarta: Kencana (Prenada Media Group). 2006 
Majalah Ilmiah Solusi

Vol. 17, No. 2 April 2019

ISSN : 1412-5331

" Halaman ini sengaja di kosongkan " 